NOTAS DE LEITURA

ANTONIOVARGAS

$\Gamma 1$

Paisagem: desdobramentos e perspectivas contemporâneas, organização de Maria Amelia Bulhões e Maria Lúcia Bastos Kern 


\section{PAISAGEM: DESDOBRAMENTOS E PERSPECTIVAS CONTEMPORÂNEAS ORGANIZAÇÃO DE MARIA AMELIA BULHÕES E MARIA LÚCIA BASTOS KERN}

Paisagem: desdobramentos e perspectivas contemporâneas (Editora da UFRGS, 20I0, 304 páginas) de vários pesquisadores, com organização de Maria Amelia Bulhões e Maria Lúcia Bastos Kern nos apresenta um conjunto de reflexões sobre as relações entre os conceitos históricos de paisagem e as produções artísticas.

$\mathrm{Na}$ primeira parte que trás o tema "Desdobramentos conceituais", Javier Maderuelo evidencia que a ideia de paisagem tal como a conhecemos é um fenômeno moderno uma vez que não encontra similares em períodos anteriores, sendo que o termo nestes (quando existe a palavra) é desprovido de um sentido contemplativo. Assim a paisagem comparece muito mais como olhar contemplativo daquele que olha do que território. A paisagem enquanto conceito cultural sujeito as particularidades de cada época já se evidenciava - ainda que esboçada - na antiguidade romana mas seria retardada em quase um milênio pelo surgimento do cristianismo. De seu ressurgir ainda em segundo plano no Renascimento até o Barroco o conceito pouco se transformaria até o Romantismo e a formulação de uma nova categoria filosófico/estética: o sublime. Mas recorda o autor, que o Romantismo dará surgimento ao conceito de Pitoresco; da paisagem bucólica, que longe de assustar se mostra acolhedora. Por fim, o autor aborda a breve negação modernista da paisagem pelo namoro com a máquina e a cidade até sua recuperação plena pela Land-art e Earthworks para nos recordar que cultivo, culto e cultura possuem uma raiz comum da qual retiramos as seivas que alimentam nosso olhar para transformar a natureza em paisagem.

$\mathrm{Na}$ segunda parte "A paisagem em perspectiva histórica", Rodrigo Gutiérrez nos apresenta algumas singularidades da relação entre a pintura de paisagem e a história e cultura latino-americanas nos séculos $X I X$ e $X X$ como consequência de transformações ocorridas em territórios europeus. Sem contraposições estereotipadas como Europa $X$ América ou Tradição $X$ Modernidade, o autor nos apresenta linhas de relações e desdobramentos como o interesse cientificista europeu e sua repercussão sobre o registro da natureza exuberante da terra nova.Também é destacada a influência romântica que encontra fertilidade nestas terras distantes não apenas para a exploração da paisagem como de outras temáticas caras ao movimento, 
como o exótico e o primitivo. Por fim o autor nos leva às relações latino-americanas entre paisagem e identidade ao analisar as transformações produzidas neste conceito artístico pela máquina, a indústria, as influência indigenistas e, como não poderia deixar, das temáticas sociais. Alexandra Kennedy-Troya, por sua vez, apresenta um ensaio no qual, com recorte entre 1850 e 1920 no Equador, busca evidenciar as relações entre a ficção e as visualidades fundacionais com a ideia de território estando esta, relacionada ao conhecimento da geografia e da agricultura local. Nacionalismo, latifúndio, política, literatura e artes visuais se mostram contaminados pelo território e sua topografia em um ensaio que auxilia na compreensão do que se costuma chamar de identidade latinoamericana. E Claudia Valladão de Mattos vem a recordar o leitor da impropriedade que é supor que as críticas ambientais sejam um fenômeno contemporâneo. A autora evidencia tal afirmação ao explicitar as relações de conhecimento de relevantes artistas, políticos e intelectuais do Século XIX com os debates e críticas sobre os danos ambientais que o progresso vinha causando sobre a flora local. Destaque para Taunay e Araújo Porto-Alegre.

Na terceira parte, "Poéticas da paisagem”, Maria Lúcia Bastos Kern aborda a paisagem na obra do uruguaio Torres-Garcia como memória-lugar e na obra do argentino Xul Solar enquanto imaginárias e místicas. Com sua elegante redação, é extremamente interessante como a autora apresenta a força do nacionalismo catalão na concepção paisagística de Torres-Garcia. De forma densa e didática é exposta a influência do Mediterranismo e do programa cultural de Eugenio D’Ors assumidos pelo uruguaio assim como, as influências e distanciamentos religiosos do Círculo Artístico São Lucas em sua concepção vanguardista. Tal exposição proporciona ao leitor uma imersão histórica e geográfica detalhada onde sequer as análises artísticas estão ausentes. Vinícius Oliveira Godoy, por sua vez, procura demonstrar a constância da paisagem nos desenhos de Iberê Camargo e os limites de suas possibilidades representativas onde, paisagem e memória se fundem na construção da modernidade artística de um dos maiores pintores brasileiros. Já Glória Ferreira analisa obras do escultor norte-americano Walter De Maria evidenciando as associações feitas pelo artista entre o tema da paisagem e a percepção de uma realidade invisível e espiritual. Para isto, De Maria elabora uma concepção de obra de arte que seja capaz de conduzir o observador a um grau de experiência possível para recordar "a potência dos abalos que percorrem a natureza” - como afirma autora. Maria Angélica Melendi, por sua vez, em um texto com uma abordagem refrescante, nos fala de jardins como paisagens não pintadas. Nos apresenta o Jardim de Bomarzo idealizado pelo príncipe Píer-Francesco Orsini (I5I3-84), cuja compreensão exige do visitante, no mínimo, conhecimentos da poesia de Dante, Petrarca e Ariosto. Passa pelo Jardim de Monet vendo a relação entre jardinar e pintar para concluir com Little Sparta, o jardim-poema criado em meio ao pântano pelo poeta escocês lan Hamilton Finlay. 
A quarta e última parte, "Poéticas digitais e questões da paisagem" fornece ao leitor uma rica introdução que permite compreender como as produções artísticas contemporâneas criadas e desenvolvidas para ambientes digitais esgarçam ainda mais os conceitos de paisagem. Iliana Hernández García investiga a heurística dos espaços virtuais imersivos sustentando que a vida artificial, ao contrário da terrestre, se apresenta como um sistema aberto sempre a pergunta e nunca a representação de respostas já obtidas. Para isto a autora comenta propostas como a de Sommerer e Mignonneau que exibem um sistema de formas orgânicas abstratas que se modificam pelas ações dos seres humanos com o sistema computacional, o projeto OP_ERA de Rejane Cantoni e Daniela Kutschat onde o corpo é participante de mudanças que se sucedem no espaço a partir de um sistema de rastreamento de uma interface, e obras de outros artistas como Maurice Benayoun, Jeffrey Shaw e Marcos Novak. Claudia Paim e Ulises Ferretti abordam a paisagem desde o campo das experimentações sonoras de seus primórdios futuristas, passando por John Cage, Westerkamp \& Andra McCartney, Pierre Schaeffer, para deter-se em Duplo Coro obra deles próprios concebida originalmente para o jardim do Departamento Municipal de Águas e Esgoto de Porto Alegre. André Parente, por sua vez, discute conceitualmente a paisagem do espaço ao ciberespaço analisando as relações entre o tempo (ou velocidade) e as topologias evidenciando que o tempo - por se constituir em unidade com o espaço - ao ser alterado nas topologias amplifica através de heterotopias as possibilidades de experiências e conhecimentos. Para ilustrar, o autor analisa projetos próprios e de outros artistas como Jean-Luc Boissier, Matt Mullican e Monika Fleishmann. Já Sandra Rey aborda seu próprio projeto DesDOBRAmentos da paisagem: um processo artístico com base na fotografia digital, no qual o conceito de deslocamento encontra-se permeado por experiências, ações e experimentações estabelecidas em determinados territórios ou lugares. Nestas experiências, processo e projeto, independentes e interdependentes, se definem no "trajeto" de uma prática, do registro não apenas do espaço mas também das vivências produtoras de arquivos cuja experimentação é geradora de imagens que amplificam e redimensionam os conceitos historiográficos da paisagem. No último texto desta coletânea, Maria Amelia Bulhões, diferenciando o simples deslocamento do ato de viajar, tece uma reflexão sobre a amplificação do conceito de paisagem pelos modos contemporâneos de apreensão visual dos territórios micro e macroscópicos propiciadas por experiências e proposições da arte contemporânea. Como a autora procura evidenciar, estas experiências artísticas com uma imagem numérica que foge da relação direta com os territórios geográficos abrem-se a transformações em si mesmas pela presença do visitante. Também ficam evidenciado as novas possibilidades relacionais com a paisagem propiciadas pela arte contemporânea através de propostas imersivas e do mergulho na imagem que altera a relação do espectador com o ambiente, exemplificadas através das obras 
de artistas como Nelson Max, Jean Boissier, Gilbertto Prado, Stephan Barron, André Parente, Michael Aschauer, Joseph Lefèvre \& Martina Koutnoyan, Adriaan Stellinwerff e Lozzano Hemmer.

Assim, Paisagem, desdobramentos e perspectivas contemporâneas, pela variedade de abordagens se oferece ao leitor como um elegante prisma que permite não apenas uma compreensão histórica de um dos conceitos e temas mais importantes da arte ocidental como também de sua sobrevivência e transformação nos dias atuais. Dos diferentes olhares, fica uma convicção que a relevância da significação espiritual, social e cultural da paisagem, bem como a sua atualidade, se dá pela potência simbólica de permitir ao homem sentir-se parte do mundo e assim, menos estranho e solitário. Por fim, cabe lembrar que o livro ainda trás um "Dossiê de imagens" coloridas que auxiliam a compreensão do neófito.

\section{ANTONIO VARGAS}

Doutor em Pintura(1992) pela Universidad Complutense de Madrid, realizou pós-doutorado (1996) na Universitat de Barcelona. É professor do Centro de Artes da UDESC e do PPGAV-UDESC. Artista visual com exposições no Brasil e no exterior. 
